\title{
A Bipartite Techno-Policy Model for River Based Water Resource Management for Sustainable Future with Special Reference To Haora River in Tripura, India
}

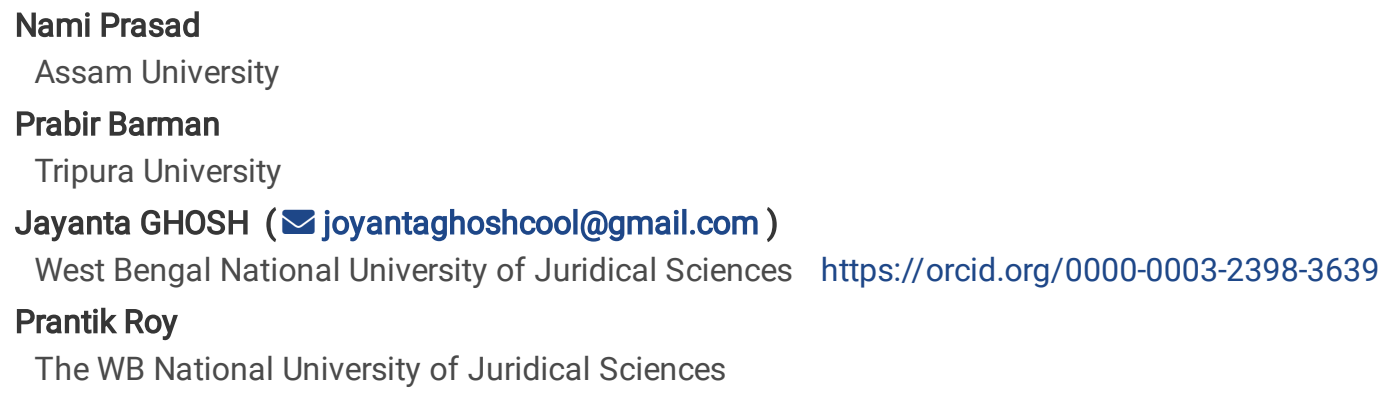

Keywords: Surface water, water quality, water quality index, ecosystem, aquatic life, statutory law

Posted Date: August 23rd, 2021

DOI: https://doi.org/10.21203/rs.3.rs-663900/v1

License: @ (1) This work is licensed under a Creative Commons Attribution 4.0 International License. Read Full License 


\section{Abstract}

Surface water serves most of the water requirements to sustain lives on earth. Of all fresh water on earth, only $1.2 \%$ is making up of surface water and the rest is confined in ice and ground. As the rivers provide for the significant sources of surface water, there is a need for river-based water resource management to meet global water quality challenge. Haora River that originated in the India's northeastern state of Tripura and meets ultimately with the Titas River in the Bangladesh carries a significant impact on life in and around the river both on the Indian side and Bangladesh side. Thus, study emphasizes the test of water quality of the river and corresponding impact therefor based on a detail explanation of the monitoring data obtained through published sources, laboratory analysis of samples and relevant field observations. ANOVA revealed year wise significant variations in physicochemical and biological properties of the river water tested except for $\mathrm{pH}$. Abnormalities were mostly observed in the values of $\mathrm{T}, \mathrm{DO}, \mathrm{BOD}, \mathrm{PO}_{4}-\mathrm{P}$ and $\mathrm{FC}$. Water Quality Index (WQI) revealed water quality status of the river fall under the category of very poor to unfit, and require proper treatment before the water is being used for drinking and other domestic purposes. Adversities in the water are also found to be affecting the aquatic life and overall river ecosystem. Cause and effect analogy of these abnormalities were established for taking corrective measures. Existing statutory law to prevent and control such anomalies have been found lacking enforcement in the state of Tripura. The broad-based state level water policy to protect and improve water resources has also been found lacking in the state. The study recommends policy level interventions at the earliest considering the specific measures suggested in this study.

\section{Introduction}

Water is one of the most essential natural resources for all existence on earth. About earth's total 1.386 billion cubic kilometers of water, $97 \%$ of water lies in the form of salt water mostly found in seas and oceans, while only $3 \%$ is considered as freshwater resources (Aniyikaiye et al., 2019). Among freshwater resources, only $0.15 \%$ of the total world's water is easily accessible for beneficial uses (Usharani et al., 2010). Water resources such as, rivers, streams, lakes, beels, seas, oceans and ground water sustain all living beings on earth. Besides, water resources are used in a variety of economic sectors such as, agriculture, raising of livestock, fisheries, industrial, hydropower generation, transportation and other recreation activities. However, the demand of global water resources has been increasing rapidly in recent years with increasing human population and urbanization (Gleick et al., 2003; Pimentel et al., 2004). Globally, $80 \%$ of the waste water including human waste to toxic industrial effluents is directly released into aquatic bodies without any treatment (UN-Water, 2018). Consequently, around 1.8 billion people are using contaminated water with faces as a source of drinking water which causes several health hazards namely, cholera, dysentery, typhoid, jaundice, and polio (UN-Water, 2018).

Further, water pollution is a major threat to environment as well as lives on earth. More than $70 \%$ of India's fresh water has been polluted by chemicals, toxic substances, thermal pollution and inorganic materials (Kurunthachalam, 2013). Mostly, rivers are being used for dumping industrial effluents, agricultural waste, municipal solid waste, untreated sewage and domestic waste. On the other hand, the major cause of degraded water quality of rivers is sewage discharged from cities and towns (Xu et al., 2013). Unfortunately, a large number of rivers in India that are basically considered as the lifeline of millions of people living along the river banks are polluted (Panigrahi and Pattnaik, 2019). With rising pollution level in rivers, water quality deteriorates persistently and is posing a severe threat to aquatic life including human beings. Thus, monitoring of water quality of rivers and other water bodies is one of the key tools to identify the pollution status and its potential threat to various uses (Lkr et al., 2020). Water Quality Index (WQI) is an important and distinctive rating to represent the overall water quality status of an aquatic system (Shah and Joshi, 2017). WQI is an effective method which summarizes large data set of water parameters into a single value that ultimately describes the water quality status of an aquatic body (Akter et al., 2016). Besides, WQI can also elucidate the overall water quality that poses a potential threat to various uses of water such as, habitat for aquatic life, irrigation water for agriculture and livestock, recreation and aesthetics, and drinking water supplies (Kumar and Dua, 2009). Therefore, a comprehensive understanding of water quality status based on WQI will be helpful to choose proper treatment method to meet the concerned issues (Tyagi et al., 2013).

India's north-eastern state of Tripura is drained by ten major rivers which originated from hills and flows either in a northern or western direction through the narrow valleys (TSPCB, 2004). The Haora River locally named as 'Saidra' is one of the ten rivers of the state. As the river passes through the capital city of the state, it fulfills the major demand of drinking water as well as water for other uses of the entire population of the city (Datta, 2006). It also fulfills the total demand of the families who inhabit near the banks of the river from Champak nagar to Bangladesh border area (TSPCB, 2004). However, anthropogenic activities such as, change in land use pattern, agricultural activities, solid waste disposal and sand mining have exerted much pressure in influencing water quality of the Haora River. Besides, inhabitants on the banks of the river are increasing very fast. Moreover, inhabitants live nearby bank areas of river without adequate sanitation facilities, unfortunately their wastes directly or indirectly flow into the river (TSPCB, 2004). Because of this, the river

Page 2/15 
water quality has deteriorated to an alarming condition. In the said backdrop, the present study aims at to analyze the physicochemical and biological properties of the water of Haora River. The study also aims at to calculate WQI to assess the water quality status of the river and potential impact therefor on a vast majority of life living in and around the river. The study further aims at to propose specific corrective measures to protect and improve the water quality of the river.

\section{Materials And Methods}

\subsection{Study area}

The state of Tripura is situated in northeastern part of India with a geographical area of $10,491.69 \mathrm{~km}^{2}$. The state is surrounded by the Bangladesh to the north, west, and south and to the east by the Indian state of Mizoram, and Assam. The state is predominantly characterized by the hilly regions. It receives heavy rainfall during monsoon and the annual rainfall varies from $1922 \mathrm{~mm}$ to $2855 \mathrm{~mm}$. The Haora River is one of the major rivers in the state of Tripura which flows through the western part of the state. The river originates from the eastern side of the Baramura Hill. After originating from Baramura range, the river flows through the places like Chandrasadhubari, Champak nagar, Debendra nagar, Jirania, Ranir bazar and the capital city Agartala falling in the west Tripura district of the Indian territory and thereafter, flows through the Bangladesh territory and ultimately meets with the Titas River in the Bangladesh. Its flow mainly depends upon the occurrence of rain and its annual water flow is 36,032 cubic meters. The river basin covers an area of $570 \mathrm{~km}^{2}$. The river is known as the lifeline of the capital city Agartala fulfilling the daily needs of water for a range of purposes of a large number of city populations. Besides, the river is the only biggest source for the local inhabitants in meeting their needs of water for drinking and other domestic purposes, farm uses including raising of livestock and fishing, industrial uses and water transportation. With the said background, the river plays a significant role as an essential water source for the inhabitants living around the river both on the Indian side as well as on the Bangladesh side.

\subsection{Sample collection}

For the collection of water samples, four sampling stations were selected based in Haora River that covers the river basin till the end part

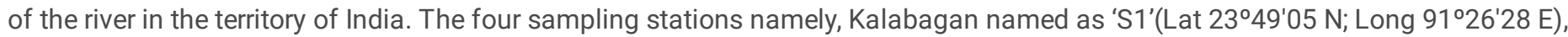

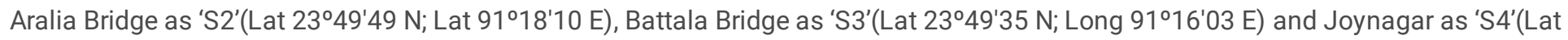
$23^{\circ} 49^{\prime} 29 \mathrm{~N}$; Long $91^{\circ} 15^{\prime} 07 \mathrm{E}$ ) are duly plotted in the map (Fig. 1). The sampling was carried out for a period of three years namely, 2018$19\left(Y_{1}\right), 2019-20\left(Y_{2}\right)$ and 2020-21 $\left(Y_{3}\right)$ at seasonal intervals in the selected sampling stations. However, for the first two years $\left(Y_{1}\right.$ and $\mathrm{Y}_{2}$ ) values of different physicochemical and biological parameters of water of Haora River published at periodic intervals by the Tripura State Pollution Control Board, the nodal agency in the domain, were taken into consideration for the present study (TSPCB, 2018; TSPCB, 2019; TSPCB, 2020). While for the third year, field visits were carried out to collect water samples from different sampling stations at seasonal intervals. Water samples were collected in PVC bottles from each of the sampling stations. Samples for dissolved oxygen and biological oxygen demand were collected separately in the BOD bottles following APHA, 2012.

\subsection{Laboratory analysis}

Analysis of $\mathrm{pH}$ and electrical conductivity $(\mathrm{EC})$ of the water samples were done using $\mathrm{pH}$ meter and $\mathrm{EC}$ meter respectively. Whereas, total dissolved solids (TDS), total suspended solids (TSS) were estimated by Gravimetric method. Turbidity (T) was analyzed using the HI 98703 Precision Turbidity meter. Samples for biological oxygen demand (BOD) were kept in an incubator at $20^{\circ} \mathrm{C}$ for five days, subsequently dissolved oxygen (DO) and BOD were estimated by Winkler's method. Other parameters such as, calcium (Ca $\left.{ }^{++}\right)$, magnesium $\left(\mathrm{Mg}^{++}\right)$, total hardness $(\mathrm{TH})$, phosphate- $\mathrm{P}\left(\mathrm{PO}_{4}-\mathrm{P}\right)$ and nitrate- $\mathrm{N}\left(\mathrm{NO}_{3}-\mathrm{N}\right)$ were analyzed following standard methods (APHA, 2012; Gupta, 2012). Besides, analysis of biological parameter such as, fecal coliform (FC) was done following membrane filtration method.

\subsection{Water quality index}

WQI is considered as most useful method of measuring overall water quality. It helps to assess the water quality status of aquatic bodies and suitability to use water for different purposes (Lkr et al., 2020). For the purpose of present study, Weighted Arithmetic Water Quality Index (WAWQI) was used (Horton, 1965; Brown et al., 1970) to measure the water quality of Haora River. Overall twelve parameters such as, $\mathrm{pH}, \mathrm{EC}, \mathrm{TDS}, \mathrm{TSS}, \mathrm{T}, \mathrm{DO}, \mathrm{BOD}, \mathrm{TH}, \mathrm{Ca}^{++}, \mathrm{Mg}^{++}, \mathrm{NO}_{3}-\mathrm{N}$ and $\mathrm{PO}_{4}-\mathrm{P}$ were used to assess the water quality index of the Haora River using water quality standards recommended by the World Health Organization (WHO), Bureau of Indian Standards (BIS), Indian Council of Medical Research (ICMR) and U.S. Environmental Protection Agency (EPA). Hence, the calculation of WQI was done by the following equations: 
Step $_{1}$ :

Calculated the unit weight (Wi) factors for each parameter by using formula

$\mathrm{Wi}=\frac{\mathrm{K}}{\mathrm{Si}}$

Where,

$\mathrm{K}=\frac{1}{\sum\left(\frac{1}{\mathrm{~s} 1}+\frac{1}{\mathrm{~s} 2}+\frac{1}{\mathrm{~s} 3}+\ldots \ldots \cdot \frac{1}{\mathrm{sn}}\right)}$

$\mathrm{K}=\frac{1}{\sum \mathrm{Si}}$

Step $_{2}$ :

Calculated the quality rating scale (Qi) value by using formula

$\mathrm{Qi}=\frac{[(\mathrm{Vi}-\mathrm{Vo})]}{[(\mathrm{Si}-\mathrm{Vo})]} \times 100$

Step $_{3}$ :

Finally, WQI was calculated by using the formula

$\mathrm{WQI}=\frac{\Sigma \mathrm{WiQi}}{\Sigma \mathrm{Wi}}$

Where,

$\mathrm{Wi}=$ unit weight for each water quality parameter;

$\mathrm{K}=$ proportionality constant;

$\mathrm{Vi}=$ concentration of $\mathrm{i}^{\mathrm{th}}$ parameter in the water sample analyzed

$V o=$ ideal value of parameter in pure water, i.e., $V o=0($ except pH 7.0 and DO $=14.6 \mathrm{mg} / \mathrm{l})$

$\mathrm{Si}=$ recommended standard value of $\mathrm{i}^{\text {th }}$ parameter;

Based on the values of WQI, water quality status of river and their possible usage was elicited following Brown et al., 1972. The detail information of WQI classification is given in Table 1.

Table 1

WQI and corresponding water quality status including possible usages

\begin{tabular}{|lll|}
\hline WQI & Water quality status & Possible usages \\
\hline $0-25$ & Excellent & Drinking, irrigation and industrial \\
\hline $26-50$ & Good & Drinking, irrigation and industrial \\
\hline $51-75$ & Poor & Irrigation and industrial \\
\hline $76-100$ & Very poor & Irrigation \\
\hline$>100$ & Unfit for drinking and fish culture & Proper treatment required before use \\
\hline
\end{tabular}




\subsection{Data visualization and Statistical analysis}

Box plots have been prepared to represent the variations in selected water parameters in all of the four sampling stations under each representative season such as, pre-monsoon, monsoon, post-monsoon and winter. The upper and lower quartiles of the data define the top and bottom of the rectangular box respectively, whereas the line inside the box represents the median value. The ends of each box are the upper and lower quartiles, so the box span is the inter-quartile range. The whiskers are the two lines outside the box that extend to the highest and lowest observations. The larger the box span of the box plot the more variable the data set is. Once the box plot outliers are identified, mild outliers are marked with small circle and 'far out', the 'extreme values' are marked with a star. To assess the overall mean, standard deviation and range of the individual water parameters of different sampling stations, MS Excel 2007 was used. One way analysis of variance (ANOVA) was used to find out the spatial-temporal variations in values of the individual parameters. In addition, Pearson correlation matrix analysis was done to see the relationship between different parameters. All statistical analyses were done using SPSS software version 20.0 (Nie et al., 2011).

\section{Results}

When considered all the sampling stations together, the mean value of $\mathrm{pH}$ of Haora River is 7.22 whereas pH ranges from 6.05 to 8.20 (Table 2). According to IS: 10500 (2012), acceptable limit of pH (max) is 8.5. However, usually a pH more than 7 makes water alkaline. Thus, obtained values of $\mathrm{pH}$ indicate that the water is slightly alkaline. Besides, box plot shows that winter had highest pH while monsoon had lowest pH (Fig. 2A). The mean value of EC of water is $153.04 \mu \mathrm{S} / \mathrm{cm}$ while it varies from 107.00 to $233.00 \mu \mathrm{S} / \mathrm{cm}$ (Table 2). As per ICMR (1975), acceptable limit (max) of EC is $300 \mu \mathrm{S} / \mathrm{cm}$. Thus, obtained values of EC are within acceptable limit. And, box plot shows that monsoon had highest EC while winter had lowest EC (Fig. 2B). The mean value of TDS is $130.13 \mathrm{mg} / \mathrm{L}$ whereas it ranges from 52.00 to $295.00 \mathrm{mg} / \mathrm{L}$ (Table 2). Thus, obtained values are within acceptable limit (max) of $500 \mathrm{mg} / \mathrm{L}$ as prescribed by the IS: 10500 (2012). Besides, box plot shows that monsoon had highest TDS while winter had lowest value (Fig. 2C). Similarly, the mean value of TSS is $31.63 \mathrm{mg} / \mathrm{L}$ while it varies from 10.00 to $75.00 \mathrm{mg} / \mathrm{L}$ (Table 2). According to WHO (2012), acceptable limit (max) is 500 $\mathrm{mg} / \mathrm{L}$ which indicates that the TSS of river water is within acceptable limit. Besides, box plot shows that monsoon had highest TSS while winter had lowest value (Fig. 2D). The mean value of T is 37.68 NTU whereas the value ranges from 4.28 to 81 NTU (Table 2). As per IS: 10500 (2012), acceptable limit of Turbidity (max) is 5 NTU, however it could be seen that T of river water is significantly higher than the acceptable limit. Box plot reveals that monsoon had highest T while post-monsoon had lowest T value (Fig. 2E). The mean value of DO is $6.62 \mathrm{mg} / \mathrm{L}$ whereas the value ranges from 5.20 to $8.08 \mathrm{mg} / \mathrm{L}$ (Table 2). According to IS 2296 (1992), the acceptable limit (min) of DO is $6.0 \mathrm{mg} / \mathrm{L}$. Thus, it is observed that the DO is much lower than the minimum acceptable limit in certain sampling stations. Besides, box plot reveals that post-monsoon had highest DO while monsoon had lowest value (Fig. 2F). The mean value of BOD is 3.26 $\mathrm{mg} / \mathrm{L}$ while the value ranges from 0.20 to $9.10 \mathrm{mg} / \mathrm{L}$ (Table 2). As per IS: 2296 (2012), the acceptable limit (max) is between 2-3 mg/L whereas it is observed that BOD of river water is much higher. Besides, box plot reveals that monsoon had highest BOD value while winter had lowest BOD (Fig. 2G). The mean value of $\mathrm{Ca}^{++}$of Haora River is $10.36 \mathrm{mg} / \mathrm{L}$ whereas it ranges from 5.93 to $25.83 \mathrm{mg} / \mathrm{L}$ (Table 2). The obtained values of $\mathrm{Ca}^{++}$of water are within acceptable limit (max) of $75 \mathrm{mg} / \mathrm{L}$ as prescribed under IS: 10500 (2012). Besides, box plot shows that pre-monsoon had highest $\mathrm{Ca}^{++}$while post-monsoon had lowest value (Fig. $\left.2 \mathrm{H}\right)$. The mean value of $\mathrm{Mg}^{++}$is $4.88 \mathrm{mg} / \mathrm{L}$ while the value ranges from 2.02 to $10.25 \mathrm{mg} / \mathrm{L}$ (Table 2). The acceptable limit (max) of $\mathrm{Mg}^{++}$is $30 \mathrm{mg} / \mathrm{L}$ as prescribed by IS: 10500 (2012). Thus, it is observed that $\mathrm{Mg}^{++}$level of river water is within acceptable limit. Besides, box plot reveals that pre-monsoon had highest $\mathrm{Mg}^{++}$while winter had lowest value (Fig. 2I). In case of $\mathrm{TH}$, the mean value is $35.71 \mathrm{mg} / \mathrm{L}$ while the value ranges from 22.44 to $69.73 \mathrm{mg} / \mathrm{L}$ (Table 2). The obtained values of TH are within acceptable limit (max) of $300 \mathrm{mg} / \mathrm{L}$ as prescribed under IS: 10500 (2012). On the other hand, box plot shows that pre-monsoon had highest TH while lowest value is observed in post-monsoon (Fig. 2J). The mean value of $\mathrm{NO}_{3}-\mathrm{N}$ of river water obtained is $0.54 \mathrm{mg} / \mathrm{L}$ whereas the value ranges from 0.10 to $1.67 \mathrm{mg} / \mathrm{L}$ (Table 2). According to IS: 10500 (2012), acceptable limit (max) is $45 \mathrm{mg} / \mathrm{L}$ which shows that the obtained values of $\mathrm{NO}_{3}-\mathrm{N}$ are within acceptable limit. And, box plot shows that winter had highest $\mathrm{NO}_{3}-\mathrm{N}$ while pre-monsoon had lowest value (Fig. 2K). In case of $\mathrm{PO}_{4}-\mathrm{P}$ of water, mean value is 0.08 $\mathrm{mg} / \mathrm{L}$ while the value varies from 0.01 to $0.18 \mathrm{mg} / \mathrm{L}$. The prescribed limit (max) for $\mathrm{PO}_{4}-\mathrm{P}$ is $0.1 \mathrm{mg} / \mathrm{L}$ as per US, EPA (1986). Thus, it is observed that obtained values are quite higher than the limit so prescribed. Besides, box plot shows that pre-monsoon had highest value of $\mathrm{PO}_{4}-\mathrm{P}$ whereas post-monsoon had lowest value (Fig. $2 \mathrm{~L}$ ). The mean value of $\mathrm{FC}$ is $120.29 \mathrm{MPN} / 100 \mathrm{ml}$ while the value ranges from 21.00 to $240.00 \mathrm{MPN} / 100 \mathrm{ml}$ (Table 2). According to IS: 10500 (2012), acceptable limit of FC is 0 MPN/100 ml while FC of river water is greatly higher as per prescribed limit. And, box plot shows that pre-monsoon had highest FC value while winter had lowest value (Fig. 2M). In case of WQI, the mean value of Haora River obtained is 96.09, while value ranges from 48.80 to 182.87 (Table 2). Besides, 
box plot reveals that monsoon had highest WQI value while winter had the lowest value (Fig. 3). On the other hand, result also indicates that the water quality status of the river water falls under the category of very poor to unfit in different seasons (Fig. 4).

Table 2

Variations in water parameters and ANOVA analysis for spatial-temporal variations in water parameters of Haora River during study period

\begin{tabular}{|c|c|c|c|c|}
\hline \multirow[t]{2}{*}{ Parameters } & \multirow[t]{2}{*}{ Overall Mean \pm SD } & \multicolumn{3}{|l|}{ F-ratio } \\
\hline & & Season-wise & Station-wise & Year-wise \\
\hline \multirow[t]{2}{*}{$\mathrm{pH}$} & $7.22 \pm 0.49$ & $6.872^{* *}$ & $2.124^{\mathrm{ns}}$ & $2.715^{\mathrm{ns}}$ \\
\hline & $(6.05-8.20)$ & & & \\
\hline \multirow[t]{2}{*}{ Electrical conductivity $(\mu \mathrm{S} / \mathrm{cm})$} & $153.04 \pm 32.44$ & $5.081^{* *}$ & $0.520^{\mathrm{ns}}$ & $13.238^{\star \star}$ \\
\hline & $(107.00-233.00)$ & & & \\
\hline \multirow[t]{2}{*}{ Total dissolved solids (mg/L) } & $130.13 \pm 80.17$ & $0.368^{\text {ns }}$ & $0.147^{\mathrm{ns}}$ & $123.828^{\star \star}$ \\
\hline & $(52.00-295.00)$ & & & \\
\hline \multirow[t]{2}{*}{ Total suspended solids (mg/L) } & $31.63 \pm 21.98$ & $0.057^{\mathrm{ns}}$ & $0.023^{n s}$ & $239.735^{\star \star}$ \\
\hline & $(10.00-75.00)$ & & & \\
\hline \multirow[t]{2}{*}{ Turbidity (NTU) } & $37.68 \pm 24.84$ & $0.250^{\mathrm{ns}}$ & $1.546^{\mathrm{ns}}$ & $88.849^{\star \star}$ \\
\hline & $(4.28-81.00)$ & & & \\
\hline \multirow[t]{2}{*}{ Dissolved oxygen (mg/L) } & $6.62 \pm 0.66$ & $1.521^{\mathrm{ns}}$ & $2.023^{\mathrm{ns}}$ & $5.640^{\star *}$ \\
\hline & $(5.20-8.08)$ & & & \\
\hline \multirow[t]{2}{*}{ Biological oxygen demand (mg/L) } & $3.26 \pm 3.18$ & $0.058^{\mathrm{ns}}$ & $0.145^{\mathrm{ns}}$ & $532.590^{\star \star}$ \\
\hline & $(0.20-9.10)$ & & & \\
\hline \multirow[t]{2}{*}{ Calcium $^{++}(\mathrm{mg} / \mathrm{L})$} & $10.36 \pm 4.07$ & $1.227^{\mathrm{ns}}$ & $2.195^{\mathrm{ns}}$ & $18.176^{\star *}$ \\
\hline & $(5.93-25.83)$ & & & \\
\hline \multirow[t]{2}{*}{ Magnesium $^{++}(\mathrm{mg} / \mathrm{L})$} & $4.88 \pm 1.81$ & $1.136^{\mathrm{ns}}$ & $1.683^{\mathrm{ns}}$ & $20.126^{* *}$ \\
\hline & $(2.02-10.25)$ & & & \\
\hline \multirow[t]{2}{*}{ Total hardness $(\mathrm{mg} / \mathrm{L})$} & $35.71 \pm 11.60$ & $0.833^{\text {ns }}$ & $2.439 \mathrm{~ns}$ & $16.563^{\star \star}$ \\
\hline & $(22.44-69.73)$ & & & \\
\hline \multirow[t]{2}{*}{ Nitrate-N (mg/L) } & $0.54 \pm 0.42$ & $1.909^{\text {ns }}$ & $1.138^{\mathrm{ns}}$ & $8.773^{* *}$ \\
\hline & $(0.10-1.67)$ & & & \\
\hline \multirow[t]{2}{*}{ Phosphate-P (mg/L) } & $0.08 \pm 0.04$ & $1.329^{\text {ns }}$ & $0.485^{\mathrm{ns}}$ & $8.057^{\star \star}$ \\
\hline & $(0.01-0.18)$ & & & \\
\hline \multirow[t]{2}{*}{ Fecal coliform (MPN/100 ml) } & $120.29 \pm 54.12$ & $4.155^{\star *}$ & $3.335^{*}$ & $6.143^{* *}$ \\
\hline & $(21.00-240.00)$ & & & \\
\hline \multirow[t]{2}{*}{ Water quality index } & $96.09 \pm 38.80$ & $1.284^{\mathrm{ns}}$ & $0.664^{\mathrm{ns}}$ & $6.101^{* \star}$ \\
\hline & $(48.80-182.87)$ & & & \\
\hline
\end{tabular}

However, one way analysis of variance (ANOVA) (Table 2) reveals year-wise significant variations in the river water in respect of all the parameters tested except $\mathrm{pH}$. However, season-wise significant variation was observed in respect of $\mathrm{pH}, \mathrm{EC}$ and $\mathrm{FC}$. While on the other, station-wise significant variation was observed in case of only FC. Further, Table 3 incorporates correlation matrix depicting the relevant 
correlation among the various parameters. The table, thus, depicts that some of the parameters showed positive or negative correlation with each other, while rest of the parameters in any way did not register any correlation with each other.

Table 3

Correlation matrix depicting the relevant correlation among various water parameters

\begin{tabular}{|c|c|c|c|c|c|c|c|c|c|c|c|c|}
\hline & $\mathrm{pH}$ & EC & TDS & TSS & $\mathrm{T}$ & DO & BOD & $\mathrm{Ca}^{++}$ & $\mathrm{Mg}^{++}$ & TH & $\mathrm{NO}_{3}-\mathrm{N}$ & $\mathrm{PO}_{4}-\mathrm{P}$ \\
\hline EC & -.237 & & & & & & & & & & & \\
\hline TDS & .249 & $.549^{* *}$ & & & & & & & & & & \\
\hline TSS & .275 & $.482^{* *}$ & $.957^{* *}$ & & & & & & & & & \\
\hline $\mathrm{T}$ & .112 & $.567^{\star *}$ & $.868^{* *}$ & $.861^{* *}$ & & & & & & & & \\
\hline DO & $.301^{*}$ & $-.553^{* \star}$ & $-.456^{\star *}$ & $-.461^{\star *}$ & $-.548^{* k}$ & & & & & & & \\
\hline BOD & $.303^{*}$ & $.572^{* *}$ & $.902^{* *}$ & $.902^{* *}$ & $.892^{* *}$ & $-.468^{* *}$ & & & & & & \\
\hline $\mathrm{Ca}^{++}$ & -.056 & -.173 & -.094 & -.026 & -.216 & .245 & -.251 & & & & & \\
\hline $\mathrm{Mg}^{++}$ & .087 & -.091 & .078 & .179 & -.022 & .158 & -.007 & $.910^{* *}$ & & & & \\
\hline $\mathrm{TH}$ & .059 & -.255 & -.093 & -.030 & -.208 & .175 & -.238 & $.875^{* *}$ & $.855^{* *}$ & & & \\
\hline $\mathrm{NO}_{3}-\mathrm{N}$ & .064 & $.503^{* *}$ & .180 & .083 & .222 & $-.405^{\star *}$ & $.304^{*}$ & $-.406^{* *}$ & $-.367^{*}$ & $-.395^{\star *}$ & & \\
\hline $\mathrm{PO}_{4}-\mathrm{P}$ & $-.289^{*}$ & .280 & $-.322^{*}$ & $-.399^{* *}$ & -.235 & .007 & -.263 & -.223 & $-.310^{*}$ & -.244 & $.368^{*}$ & \\
\hline $\mathrm{FC}$ & -.237 & .021 & -.036 & .055 & .125 & -.023 & -.045 & $.385^{\star *}$ & $.407^{* *}$ & $.333^{*}$ & $-.345^{*}$ & -.150 \\
\hline
\end{tabular}

$\mathrm{n}=48 ; * \star \mathrm{p}<0.01 ; * \mathrm{p}<0.05$

EC-Electrical conductivity; TDS-Total dissolved solids; TSS- Total suspended solids; T- Turbidity; DO-Dissolved oxygen; BODBiological oxygen demand;

Ca- Calcium; Mg- Magnesium; TH- Total hardness; $\mathrm{NO}_{3}$-N-Nitrate-nitrogen; $\mathrm{PO}_{4}$-P-Phosphate-phosphorous; FC- Fecal coliform

\section{Discussion}

Based on the results, it is evident that the values of some of the water parameters like T, DO, BOD, $\mathrm{PO}_{4}-\mathrm{P}$ and FC are not satisfactory as per standard limits prescribed by the various international and national regulatory bodies. Thus, higher values of $\mathrm{T}$ observed in water samples could be attributed to the presence of suspended particles that might have caused mostly by the increasing activities of sand mining carried out in the river. Besides, heavy soil erosion occurs every year due to flood might led to greater T value in monsoon. Similar kind of observation has been reported in like studies by many authors (Narain and Chauhan, 2000; Almeida et al., 2012; Gupta et al., 2017). Abnormalities found in DO values of water samples could be attributed to the excessive growth of algae that might have largely caused by input of organic matter, entry of household waste and dumping of municipal solid waste containing plastics into the river. Moreover, It may be mentioned here that DO showed significant negative correlation with EC ( $r=-.553)$, TDS ( $r=-.456)$, TSS ( $r=-.461)$ and T $(\mathrm{r}=-.548)$, while positive correlation with $\mathrm{pH}(\mathrm{r}=.301)$. With regard to this, it can be stated that existence of suspended particles and particulate matters in the river water might have affected the light availability to the photosynthetic organisms which eventually reduced the DO level in water. On the contrast, high values of BOD observed in water samples could be attributed to the greater influx of organic materials by human activities such as, bathing, washing clothes and utensils along with sewage discharged into the river. Besides, decomposition of dead plants and other aquatic organisms might have increased the microbial activities which led to increasing level of BOD in water. This is also supported by the negative correlation recorded between BOD and DO $(r=-.468)$. Again, observed value of $\mathrm{PO}_{4}-\mathrm{P}$ is high in water samples could be attributed to the entry of agricultural runoff, industrial effluents and greater input of phosphorus rich materials such as, soaps and detergents into the river. Additionally, immersion of idols observed in the study area might have caused greater concentration of $\mathrm{PO}_{4}-\mathrm{P}$ in water. Further, high levels of $\mathrm{FC}$ in water samples could be attributed to entry of untreated sewage, livestock manure and human fecal matters directly into the river. The findings recorded above in the present study were corroborated by the similar findings recorded in like cases in a previous study (Sarkar and Mishra, 2014). Notably, ANOVA results reveal 
year-wise significant variations in the river water in respect of all the parameters tested except $\mathrm{pH}$. This could be attributed to the variation in several factors such as, rainfall, seasonal fluctuations and intensity of solar radiation in the study area. Additionally, anthropogenic activities also have contributed to such wide variations in water parameters.

From the above discussion, it can be clearly seen that the quality of river water has begun to get deteriorated which in turn likely to affect the aquatic life as well as river ecosystem. In recent years, it has been seen that there are enormous reduction in fish diversity, turtle species and other benthic organisms in the study area. Many authors also stated that degraded water quality affects the biodiversity of aquatic communities in rivers (Akhtar and Nawaz, 2012; Mustapha et al., 2013; Xu et al., 2013; Akpe et al., 2018). Moreover, obtained values of WQI indicate that the water quality status of the river falls under the category of very poor to unfit. Therefore, it clearly signifies that water is not suitable for drinking purpose as well as for other domestic uses without proper treatment. Consequently, a large number of people who are dependent on the river for their daily needs are found to be affected in the study area by water borne diseases such as, typhoid, diarrhoea, dysentery, cholera, malaria, jaundice, skin itching and infection. Moreover, poor water quality and lack of proper sanitation facility plays a vital role in spreading infectious diseases that are presently emerging and creating an immense public health problem (Kothari et al., 2021). According to WHO reports, $80 \%$ of all human illness in the developing countries is associated with polluted water (Witt, 1982). Remarkably, every year more than 5 million people die due to water related diseases worldwide (Malik et al., 2012). Among the water borne diseases, diarrhoea only kills nearly one million people annually (Levallois and Villanueva, 2019). Thus, based on the present water quality status of the Haora River which is found to be polluted and dangerous for aquatic life and human health, there is a need for monitoring the water quality of Haora River on regular basis through state intervention.

At a global level, United Nations Water Conference in which India was also a signatory evolved an Action Plan as the first internationally coordinated approach to Integrated Water Resource Management. The Action Plan recognized, inter alia, that "All people, whatever their stage of development and their social and economic conditions, have the right to have access to drinking water in quantum and of a quality equal to their basic needs". Clean and safe water is a basic need for human. The Constitution of India does not directly deal with the problem of water quality. Although, the Courts in India over the years have expanded the scope of fundamental "Right to Life" falling under Article 21 of the Constitution through several landmark judgments to include right to clean and safe water as one of the prerequisites of "Right to Life". Besides, the two keystone objectives mentioned in the Directive Principles of State Policy (Part IV) of the Constitution are (i) to enhance the general health of the citizens (Article 47), and (ii) to safeguard the natural environment (Article 48A). Further, environmental conservation and enhancement have been declared a requirement in the Constitution [Article 51A (g)].

In furtherance of the Constitutional obligations, Legislature in India (Union) has enacted the Water (Prevention and Control of Pollution) Act, 1974 (commonly referred to as the "Water Act of 1974"). The Act applies to the state of Tripura by a resolution passed in this behalf by the State Legislature in pursuance of the clause (1) of Article 252 of the Constitution. Sections 3 and 4 of the Act respectively provide directive for constitution of the Central as well as State Boards wherever the Act applies for prevention and control of water pollution within their respective territories. Sections 16 and 17 of the Act respectively enumerated the functions of such Central and State Pollution Control Boards. Anybody who knowingly places or permits the entry of any 'poisonous, noxious or polluting' matter into the water bodies or on land except in accordance with such criteria and standards as may be prescribed by the State Pollution Control Boards shall be held liable under the Act. The State Pollution Control Board is responsible for determining whether a particular matter is 'poisonous, noxious or polluting' and the corresponding criteria and standards of its disposal. Section 17(1)(a) of the Act imposes a statutory obligation on the State Pollution Control Board to prepare and execute within the state a comprehensive program for the prevention, control and abatement of pollution of water-bodies.

The present study finds that the Water Act of 1974 though applies in the state of Tripura, lacks proper and systematic execution thereof in its letter and spirit. The similar finding has been reported in a previous study carried out on the subject matter in question (Ghosh et al., 2021). Moreover, the National Water Policy formulated under the aegis of the Ministry of Water Resources, Government of India suggests formulation and implementation of the local level policy vis-a-vis the national policy for 'Repair, Renovation and Restoration' of water bodies. Thus, there is a need for formulation and implementation of specific State Water Policy that is presently lacking in the state of Tripura for protection and improvement of water bodies in the state including the Haora River keeping in mind the significance of water resources to life, livelihood, food supply and consequently, the sustainable future of the state. The said policy should provide for the river restoration schemes like afforestation, managing catchment areas, adoption of boulder clusters and concrete structure forge at river bank to protect and ameliorate the river health. The policy should also provide for the prevention of the existing day-to-day discharge of untreated sewage including industrial effluents directly into the river, and also the prevention of the disposal of solid waste including household consumption residues into the river through setting up of alternative dumping stations. The policy, further, should provide for mass awareness campaign to be initiated involving concerned state administration including state pollution control board,

Page 8/15 
district level authorities, municipal corporations, industry houses, NGOs etc., to encourage the local communities to know about the benefits of such river restoration. In addition, one dedicated nodal agency namely, the State Water Resources Council should be set up in the state to monitor the implementation persistently of such policy.

\section{Conclusions}

To conclude it is pertinent to mention that steps should be taken on urgent basis for correction of abnormalities noted based on the obtained results and relevant observations through checks and balances on regular basis. As water resources management is a key to address the global water quality challenge and sustainable development goals, the present study has been designed to provide for an early warning system against any potential threat to the Haora River. Thus, it's an alarming time for the national and local governments including the communities living around the river to remain vigilant and cautious as to any further deterioration of the water quality and ecology of the river. Hence, it is highly recommended for broad based policy level interventions at the earliest through the adoption of specific measures suggested in this study.

\section{Declarations}

Ethical Approval - Not Applicable.

Consent to Participate - Not Applicable.

Consent to Publish - Yes Author has giving the permission to publish.

\section{Authors Contributions}

Conceptualization: Prantik Roy, Jayanta Ghosh; Methodology: Nami Prasad, Prabir Barman; Formal analysis and investigation: Nami Prasad, Prabir Barman; Writing - original draft preparation: Nami Prasad, Prabir Barman, Jayanta Ghosh, Prantik Roy; Writing - review and editing: Nami Prasad, Prabir Barman, Jayanta Ghosh, Prantik Roy;

Competing Interests - Not Applicable.

\section{Acknowledgements}

The authors are grateful to the Department of Forestry and Biodiversity, Tripura University, Suryamaninagar, India for providing laboratory facilities. The authors are also grateful to the Member-Secretary, Tripura State Pollution Control Board for providing guidance in getting relevant previous data collected for the purpose of the present work. Further, the authors acknowledge the support received from the Centre for Regulatory Studies, Governance and Public Policy, the WB National University of Juridical Sciences, Kolkata, India to undertake this collaborative work.

\section{Funding}

This research did not receive any grant from any funding agencies in the public, commercial, or not-for-profit sectors.

\section{Data availability and Material}

The authors of this work authorize the corresponding author to share the relevant data set on which the present work is based specifically on request being made in this behalf upon reasonable grounds.

\section{References}

1. Akhtar S, Nawaz M (2012) Impact of water quality on aquatic life in River Ravi, Pakistan. Nat Environ Pollut Technol 11(2):219-224

2. Akpe AR, Femi IJ, Okwu Gl, Obiazi H (2018) Seasonal Variations in the Physicochemical Parameters of Ikpoba River Water Samples. Int J Life Sci Scienti Res 4(3):1810-1821. http://dx.doi.org/10.21276/ijlssr.2018.4.3.12

3. Akter T, Jhohura FT, Akter F, Chowdhury TR, Mistry SK, Dey D, Barua MK, Islam MA, Rahman M (2016) Water Quality Index for measuring drinking water quality in rural Bangladesh: a cross-sectional study. J Health Popul Nutr 35(1):1-12.

https://doi.org/10.1186/s41043-016-0041-5 
4. Almeida C, González So, Mallea M, González P (2012) A recreational water quality index using chemical, physical and microbiological parameters. Environ Sci Pollut Res 19(8):3400-3411. https://doi.org/10.1007/s11356-012-0865-5

5. Aniyikaiye TE, Oluseyi T, Odiyo JO, Edokpayi JN (2019) Physico-chemical analysis of wastewater discharge from selected paint industries in Lagos, Nigeria. Int. J. Environ. Res. Public Health 16(7), 1235. https://doi.org/10.3390/ijerph16071235

6. APHA (2012) Standard Methods for Examination of Water and Wastewater, 22nd edn. American Public Health Association, New York

7. Brown RM, McClelland NI, Deininger RA, O'Connor MF (1972) A water quality index-crashing the physiological barrier. In: Thomas WA (ed) Indicators of Environmental Quality. Environmental Science Research, Springer, Boston, pp 173-182. https://doi.org/10.1007/978-1-4684-2856-8_15

8. Brown RM, McClelland NI, Deininger RA, Tozer RG (1970) A water quality index-do we dare. Water Sew Works 117:339-343

9. Bureau of Indian Standards (IS 10500) (2012) Drinking water specification. https://law.resource.org/pub/in/bis/S06/is.10500.2012.pdf (accessed 21April 2021)

10. Bureau of Indian Standards (IS 2296) (1992) Surface water quality standards. https://elibraywcl.files.wordpress.com/2015/02/surface-water-quality-standards-as-per-is-2296.pdf (accessed 19April 2021)

11. Datta S (2006) A study on water system analysis of Haora river basin Tripura an integrated approach. PhD Thesis, Jadavpur University, India

12. Ghosh J, Barman P, Roy P (2021) Right to clean water: a case study of Gomati River in Tripura, India from techno-socio-legal perspectives. Sustain Water Resour Manag 7(2):1-8. https://doi.org/10.1007/s40899-021-00501-3

13. Gleick PH (2003) Global freshwater resources: soft-path solutions for the 21st century. Sci 302(5650):1524-1528. http://dx.doi.org/10.1126/science.1089967

14. Gupta N, Pandey P, Hussain J (2017) Effect of physicochemical and biological parameters on the quality of river water of Narmada, Madhya Pradesh, India. Water Sci 31(1):11-23. https://doi.org/10.1016/j.wsj.2017.03.002

15. Gupta PK (2012) Methods in environmental analysis water, soil and air, 2nd edn. AGROBIOS, India

16. Horton RK (1965) An index number system for rating water quality. J Water Pollut Control Fed 37(3):300-306

17. Indian Council of Medical Research (ICMR) (1975) Manual of standards of quality for drinking water supplies, 2nd edn. Indian Council of Medical Research, Special Report Series No.44:27, New Delhi

18. Kothari V, Vij S, Sharma S, Gupta N (2021) Correlation of various water quality parameters and water quality index of districts of Uttarakhand. Environ Sustain Indic 9:100093. https://doi.org/10.1016/j.indic.2020.100093

19. Kumar A, Dua A (2009) Water quality index for assessment of water quality of river Ravi at Madhopur (India). Glob J Environ Sci 8(1), 49-57. http://dx.doi.org/ 10.4314/gjes. v8i1.50824

20. Kurunthachalam SK (2013) Indian waters: past and present. Hydrol. Current Res S10(2):1-8. http://dx.doi.org/10.4172/21577587.S10-001

21. Levallois P, Villanueva CM (2019) Drinking water quality and human health: an editorial. Int J Environ Res Public Health 16(4):631. https://doi.org/10.3390/ijerph16040631

22. Lkr A, Singh MR, Puro N (2020) Assessment of water quality status of Doyang River, Nagaland, India, using water quality index. Appl Water Sci 10(1):1-13. https://doi.org/10.1007/s13201-019-1133-3

23. Malik A, Yasar A, Tabinda AB, Abubakar M (2012) Water-borne diseases cost of illness and willingness to pay for diseases interventions in rural communities of developing countries. Iran J Public Health 41(6):39-49

24. Mustapha A, Aris AZ, Juahir H, Ramli MF, Kura NU (2013) River water quality assessment using environmentric techniques: case study of Jakara River Basin. Environ Sci Pollut Res 20(8):5630-5644. https://doi.org/10.1007/s11356-013-1542-z

25. Narain S, Chauhan R, 2000. Water Quality Status of River Complex Yamuna at Panchnada Distt. Etawah, UP, (India). I: An Integrated Management Approach. Pollut. Res. 19(3), 357-364

26. Nie N, Hull C, Bent D (2011) IBM statistical package for the social sciences (SPSS Version 20). Computer Software. SPSS, Chicago

27. Panigrahi AK, Pattnaik S (2019) A Review on Consequences of Pollution of Some Indian Major Rivers and Their Remedial Measures. Int J Res Rev 6(7):373-383

28. Pimentel D, Berger B, Filiberto D, Newton M, Wolfe B, Karabinakis E, Clark S, Poon E, Abbett E, Nandagopal S (2004) Water resources: agricultural and environmental issues. Bioscience 54(10):909-918. https://doi.org/10.1641/0006-

3568(2004)054[0909:WRAAEI]2.0.CO;2

Page 10/15 
29. Sarkar S, Mishra U (2014) Analysis on water quality of Haora River in Agartala with an assessment of Water Quality Index. Int J Civ Eng Res 5(4):447-452

30. Shah KA, Joshi GS (2017) Evaluation of water quality index for River Sabarmati, Gujarat, India. Appl Water Sci 7(3):1349-1358. https://doi.org/10.1007/s13201-015-0318-7

31. Tripura State Pollution Control Board (TSPCB) (2004) Pollution Status Assessment of Haora River, Tripura. pp. 1-12. http://trpenvis.nic.in> test > doc_files > Haora river (accessed 25 May 2021)

32. Tripura State Pollution Control Board (TSPCB) (2018) https://tspcb.tripura.gov.in/water-quality-monitoring/ (accessed 23March 2021).

33. Tripura State Pollution Control Board (TSPCB) (2019) https://tspcb.tripura.gov.in/water-quality-monitoring/ (accessed 23 March 2021).

34. Tripura State Pollution Control Board (TSPCB) (2020) https://tspcb.tripura.gov.in/water-quality-monitoring/ (accessed 23 March 2021).

35. Tyagi S, Sharma B, Singh P, Dobhal R (2013) Water quality assessment in terms of water quality index. American Journal of water resources 1(3), 34-38. https://doi.org/10.12691/ajwr-1-3-3

36. Water UN- (2018) Water quality and waste water. http://www.unwater.org > app > uploads > 2018/10 (accessed 25May 2021)

37. United States of Environmental Protection Agency (US EPA) (1986) Quality Criteria for Water. Gold Book Quality Criteria, EPA 440/586-001. Office of Water, Washington. https://www.epa.gov > production > files > documents (accessed 10 June 2021)

38. Usharani K, Umarani K, Ayyasamy PM, Shanthi K, Lakshmanaperumalsamy P (2010) Physico-chemical and bacteriological characteristics of Noyyal River and ground water quality of Perur, India. J Appl Sci Environ Manag 14(2):29-35. https://doi.org/10.4314/jasem.v14i2.57830

39. Witt VM (1982) Developing and applying international water quality guidelines. J Am Water Works Assoc 74(4):178-181. https://doi.org/10.1002/j.1551-8833.1982.tb04885.x

40. World Health Organizations (WHO) (2012) Guidelines for drinking water quality. https://apps.who.int/iris/bitstream/handle/10665/44584/9789241548151_eng.pdf?sequence=1 (accessed 18April 2021)

41. Xu M, Wang Z, Duan X, Pan B (2013) Effects of pollution on macroinvertebrates and water quality bio-assessment. Hydrobiologia 729(1):247-259. https://doi.org/10.1007/s10750-013-1504-y

\section{Figures}




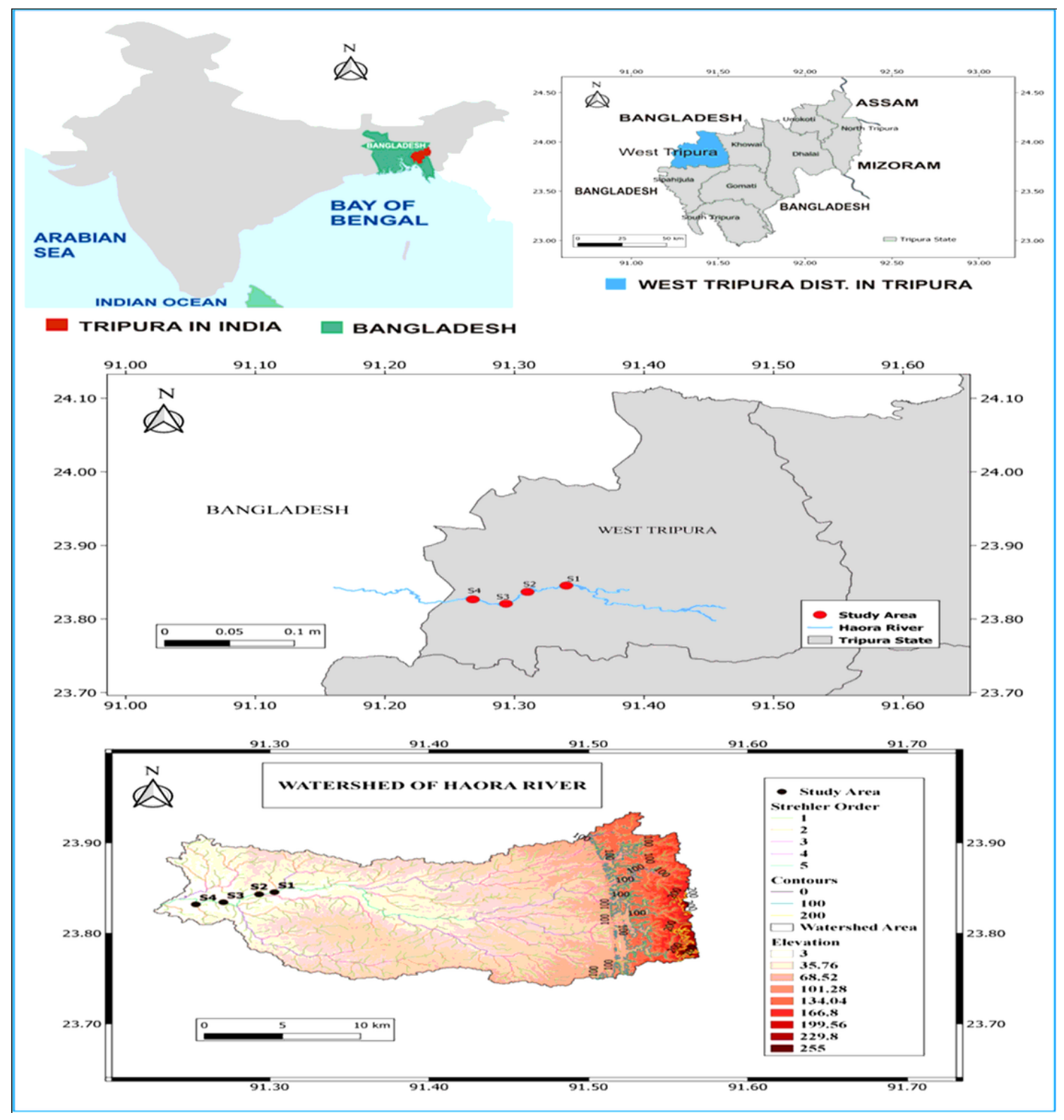

\section{Figure 1}

Map showing the study area and specific sampling stations 

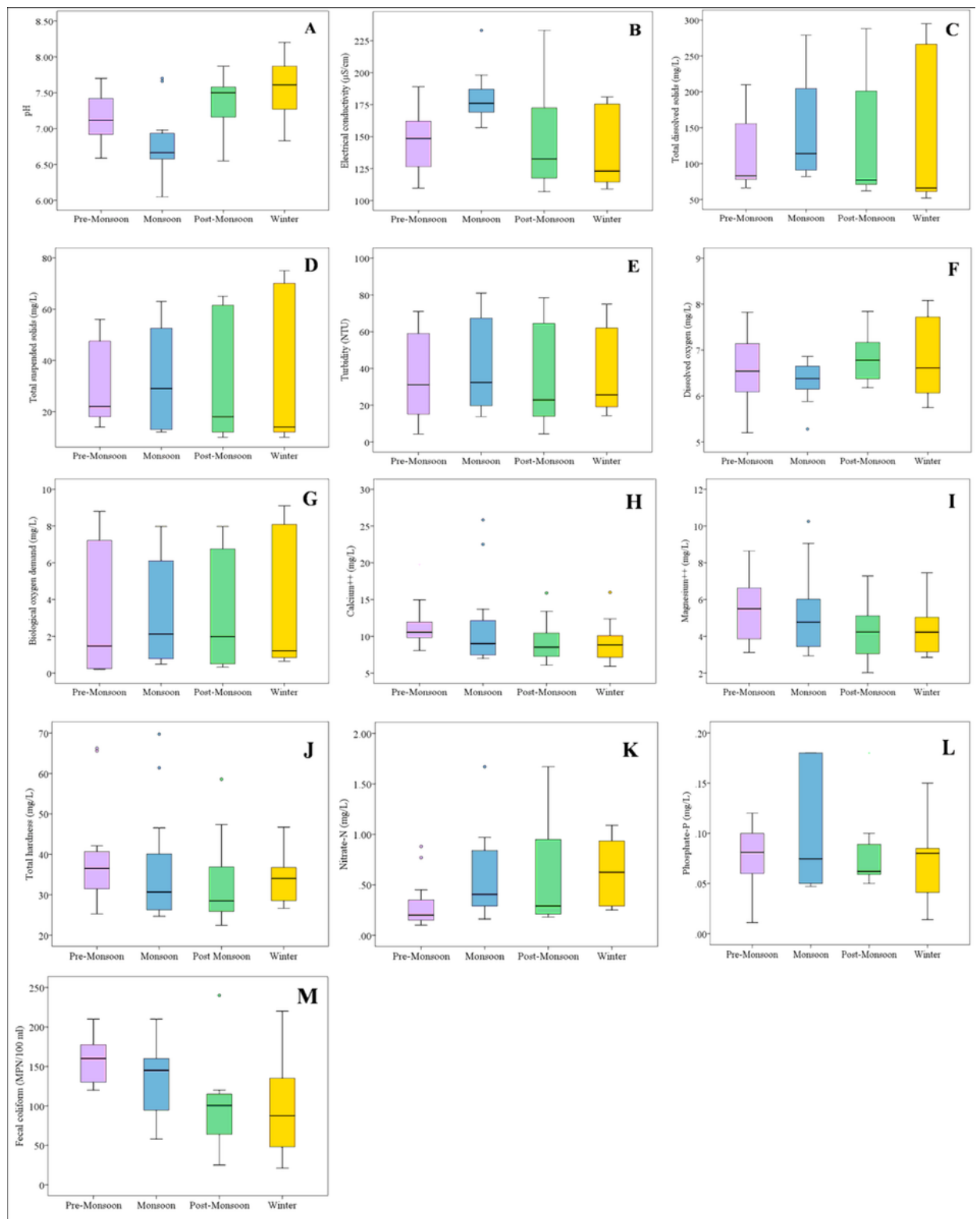

Figure 2

Seasonal variations in selected water parameters of Haora River during study period 


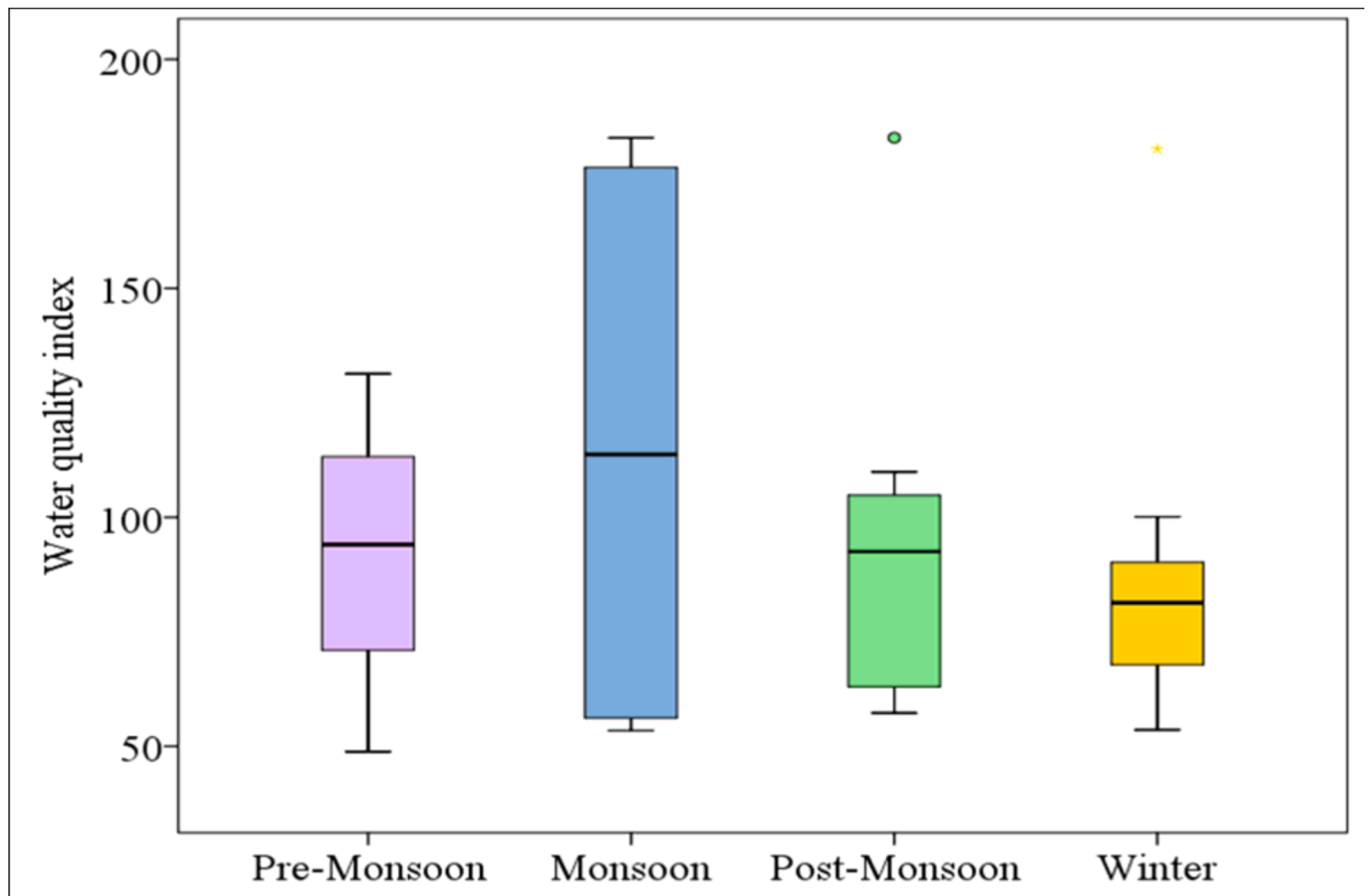

Figure 3

Seasonal variations in water quality index of Haora River during study period 


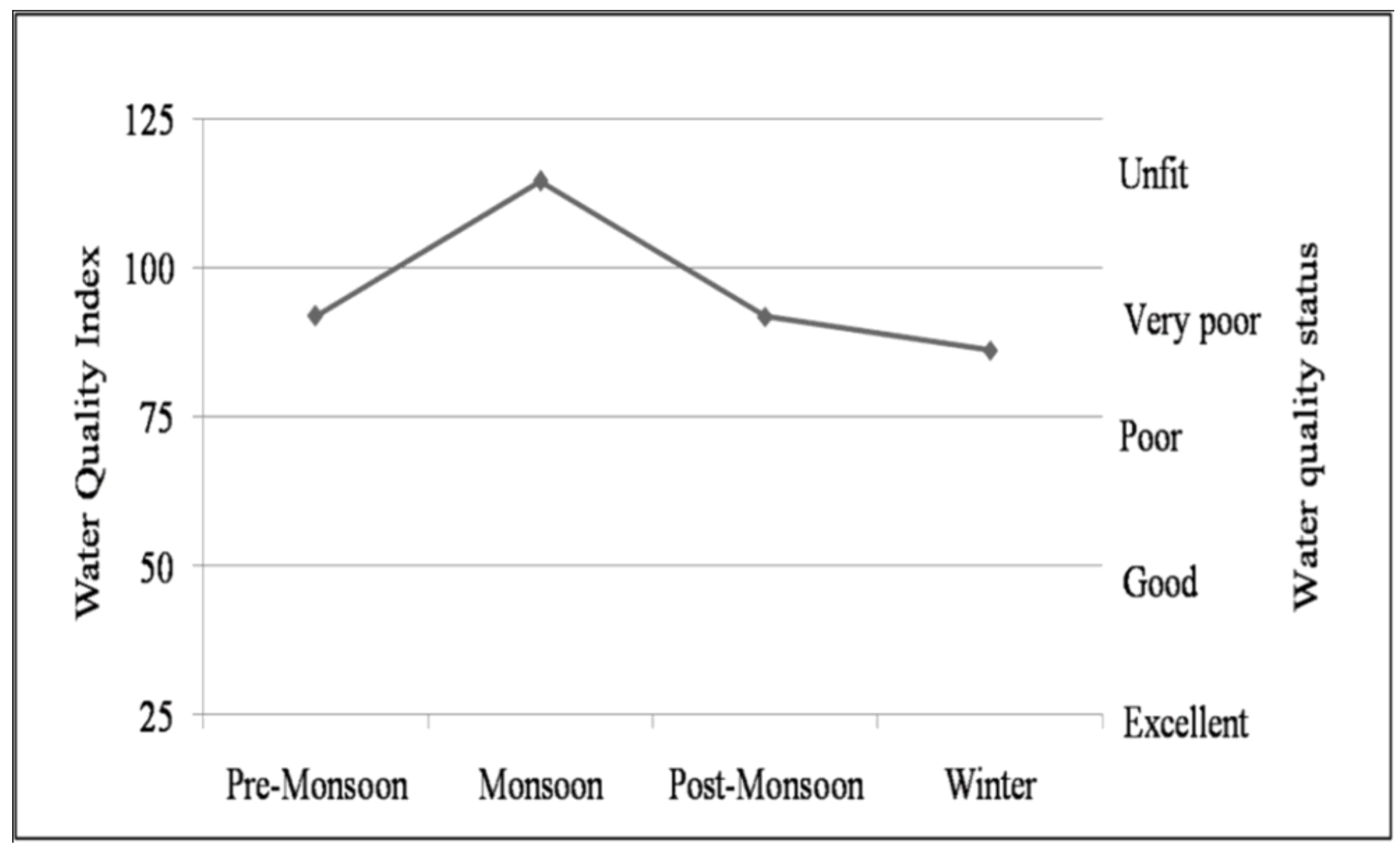

Figure 4

Water quality status of Haora River in different seasons during study period 